\title{
$N$-Propargylamines: versatile building blocks in the construction of thiazole cores
}

\author{
S. Arshadi ${ }^{* 1}$, E. Vessally ${ }^{1}$, L. Edjlali ${ }^{2}$, R. Hosseinzadeh-Khanmiri ${ }^{2}$ \\ and E. Ghorbani-Kalhor ${ }^{2}$
}

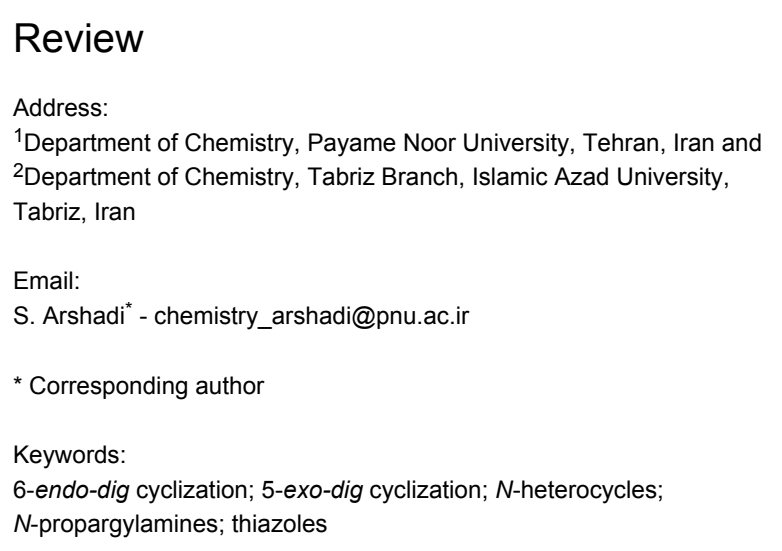

Beilstein J. Org. Chem. 2017, 13, 625-638. doi:10.3762/bjoc. 13.61

Received: 10 December 2016

Accepted: 06 March 2017

Published: 30 March 2017

Associate Editor: J. Aubé

(C) 2017 Arshadi et al.; licensee Beilstein-Institut. License and terms: see end of document.

\begin{abstract}
Thiazoles and their hydrogenated analogues are not only key structural units in a wide variety of natural products but they also constitute important building blocks in medicinal chemistry. Therefore, the synthesis of these compounds using new protocols is always interesting. It is well known that $\mathrm{N}$-propargylamines can undergo a number of cyclization reactions to produce various nitrogen-containing heterocycles. In this review, we highlight the most important developments on the synthesis of thiazole and its derivatives starting from $N$-propargylamines. This review will be helpful in the development of improved methods for the synthesis of natural and biologically important compounds.
\end{abstract}

\section{Introduction}

Thiazoles are an important class of azole compounds that have attracted considerable attention due to the fact that they exhibit a wide variety of pharmacological activities. For example, abafungin (Figure 1) is an antifungal drug marketed worldwide for the treatment of dermatomycoses. It works by inhibiting the enzyme sterol 24-C-methyltransferase [1-4]. Febuxostat, also known by its brand name adenuric is a xanthine oxidase inhibitor that helps to prevent gout flare-ups [5-7]. Ritonavir (norvir), is an HIV protease inhibitor. It works by blocking the growth of HIV [8,9]. Tiazofurin is a C-nucleoside analogue with antineoplastic activity and acts by inhibition of the guanosine triphos- phate (GTP) biosynthesis through a reduction of PI and PIP kinase activity [10-14] (Figure 1). This compound class is also a crucial part of many natural products such as vitamin B1 (thiamine), epothilone, dolastatin, and many more (Figure 2) [15-24]. Moreover, thiazoles are widely applied as pesticides and dyes [25]. As a consequence, many routes for the synthesis of thiazole derivatives are reported in the literature [26-33]. Among them, the Hantzsch thiazole synthesis (condensation of $\alpha$-haloketones with thioamides) is the most efficient and straight forward procedure [34-43]. However, the general applicability of this method is limited by the narrow substitution 


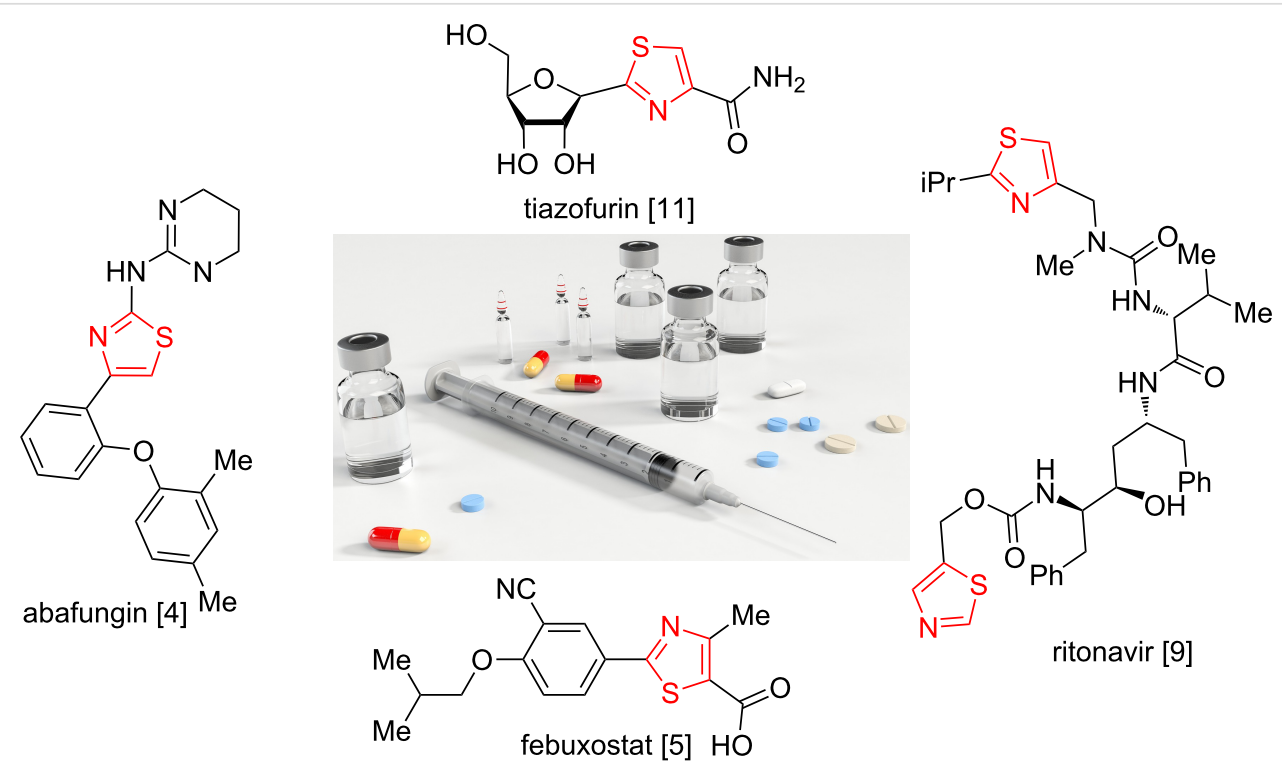

Figure 1: Selected examples of bioactive thiazole derivatives.

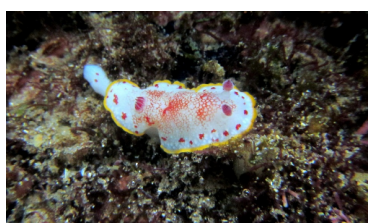

Nudibranch, e.g.,

$H$. sanguineus $[15,19]$

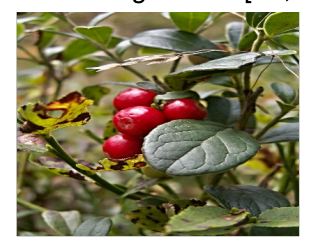

Plants, e.g., American cranberries $[17,22]$

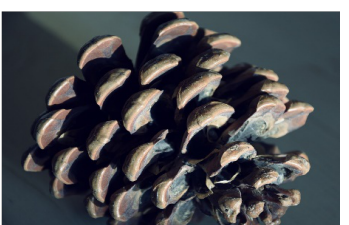

Seed, e.g., pine nut $[16,20]$

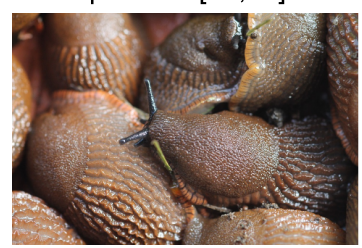

Sea slug, e.g.,

Pleurobranchus forskalii $[15,23]$

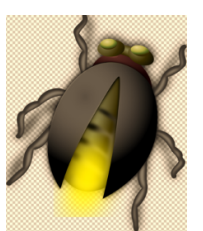

Insects, e.g. firefly $[17,21]$

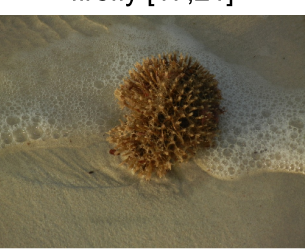

Marine sponge, e.g., Discodermia calyx [15,24]

Figure 2: Some natural sources of thiazoles.

patterns [31], by the harsh reaction conditions [26,30] or both. Therefore, methods that overcome these drawbacks are required.

The hydrogenated thiazoles (thiazoline and thiazolidine derivatives) are also important structural motifs that are widely found in biologically active natural or synthetic products [44-50]. Compounds containing these rings have widespread biological applications as anticancer [51-53], anti-HIV [54,55], antiinflammatory [56], antimicrobial [57-59], and specially antibiotic [60-64] agents. Despite their great relevance in drug design, only very few synthetic methods towards these compounds have been reported to date [44].
$\mathrm{N}$-Propargylamines are one of the most specific class of alkynes having diverse reaction patterns. It is well known that they can undergo a number of cyclization reactions to produce various $N$-heterocycles and complex natural products. In this context we recently reviewed their role in the syntheses of pyrrole [65], pyridine [66], quinoline [67], pyrazine [68], 1,4-oxazepane, and 1,4-diazepane [69] derivatives. The synthesis of thiazoles and their hydrogenated analogues from $N$-propargylamines offers several advantages, such as high functional group tolerance and high atom and step economy. In continuation of our works [6974], in this review, we will highlight the most important developments on the synthesis of thiazole and its derivatives from $\mathrm{N}$-propargylamines (Figure 3 ) which will be helpful in the de- 


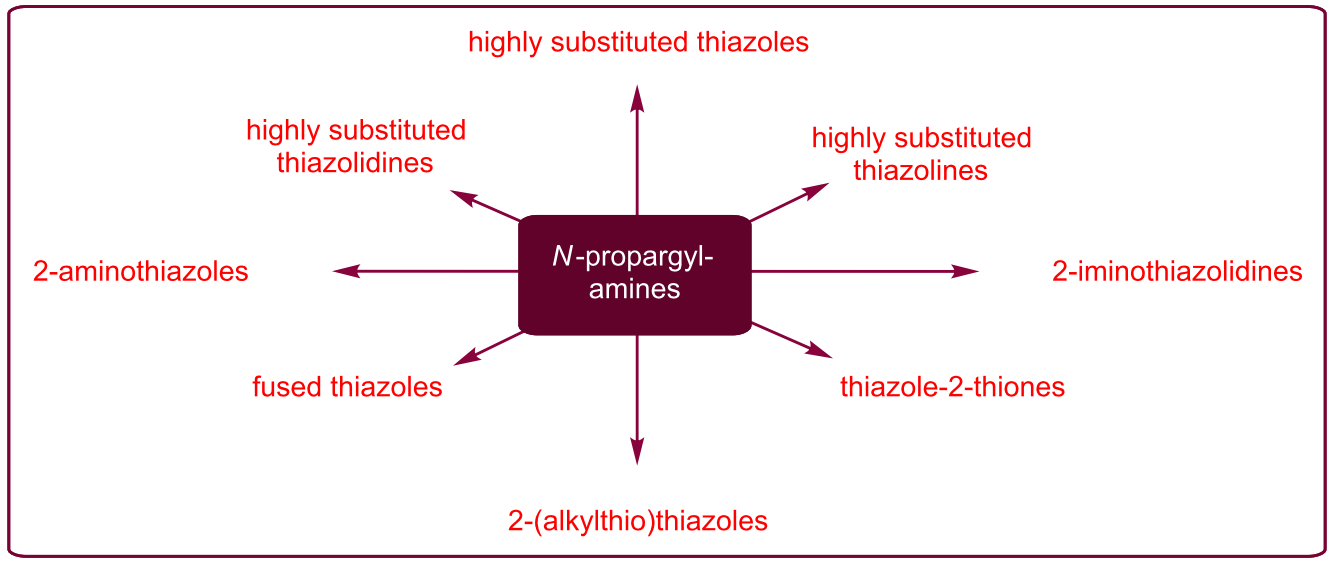

Figure 3: Some important thiazole-based compounds derived from $\mathrm{N}$-propargylamines.

velopment of improved methods for the synthesis of natural and biologically important compounds. The review is organized by the type of starting materials.

\section{Review}

\section{From $\mathrm{N}$-propargylamines and carbon disulfide}

The first example of a cyclization of $N$-propargylamines 1 with carbon disulfide to lead to 5-methylenethiazolidine-2-thiones 2 was reported in 1949 by Batty and Weedon. The reaction took place in refluxing ethanol and generally afforded the corresponding products in good yields. It was also observed that products $\mathbf{2}$ rapidly formed by reaction of $\mathbf{1}$ with carbon disulfide in the presence of sodium hydroxide as the base in water at $20{ }^{\circ} \mathrm{C}$. Further, the authors showed that treatment of methylene compound 2 with cold concentrated sulfuric acid gave the corresponding isomeric thiazole-2-thiones 3 in high yields (Scheme 1) [75]. Thirty-six years later, Hanefeld and Bercin synthesized a series of 2-(alkylthio)thiazoles by employing the aforementioned method as the key step [76]. In 2001, Shi and Shen found that using a $\mathrm{Pd}\left(\mathrm{PPh}_{3}\right)_{4} /$ toluene system clearly accelerated this cyclocondensation and the desired products were ob- tained in excellent yields [77]. Other systems such as $\mathrm{Pd}(\mathrm{OAc})_{2} /$ THF [78], D301R (a tertiary amine-functionalized ion-exchange resin)/biphenyl [79], and diethylamine/ $\mathrm{NaOH} / \mathrm{H}_{2} \mathrm{O}$ [80] were also successfully employed in this transformation. Despite all these successes, the number of reported examples in this interesting field is limited. There is still further need to study the scope and limitations of this approach for the preparation of thiazolidine-2-thione derivatives.

A straightforward way towards 2-benzylthiazolo[3,2-a]benzimidazole derivatives 6 has been proposed by Balova et al. In their approach, a sequential cyclocondensation/5-exo-dig cyclization process between 2-amino- $N$-propargylanilines $\mathbf{4}$ and $\mathrm{CS}_{2}$ afforded heterocyclic systems of type 5. Isomerization of the latter compounds upon heating in the presence of $\mathrm{KOH}$ in ethanol gave the corresponding 2-benzylthiazolo[3,2-a]benzimidazoles 6 in good yields (Scheme 2a) [81]. In a closely related investigation, Shafiee and co-workers also found that the cyclocondensation of 2-amino- $N$-propargylbenzamides 7 with $\mathrm{CS}_{2}$ in a $\mathrm{KOH} / \mathrm{EtOH}$ system gave the corresponding 2-methylenethiazolo[2,3-b]quinazolinones 8 in good to high yields (Scheme $2 b$ ) [82].

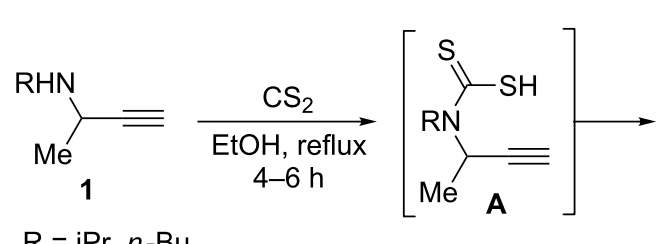

$\mathrm{R}=\mathrm{iPr}, n-\mathrm{Bu}$, $c$-Hex, Bn

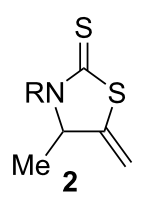

conc. $\mathrm{H}_{2} \mathrm{SO}_{4}$

4 examples (58-81\%)

(average yield: $71 \%$ )

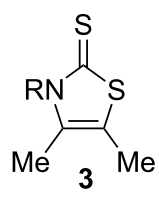

4 examples (80-90\%) (average yield: $85 \%$ ) 
a)<smiles>[R]C#CCNc1ccccc1N</smiles>

4a, $R=P h$

$4 \mathrm{~b}, \mathrm{R}=4-\mathrm{Br}-\mathrm{Ph}$

4c, $\mathrm{R}=4-\mathrm{OMe}-\mathrm{Ph}$

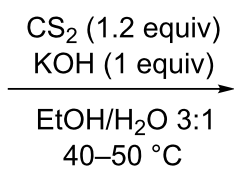

$\overbrace{R}^{N}$

6a, $(93 \%)$

6b, $(93 \%)$

6c, $(95 \%)$

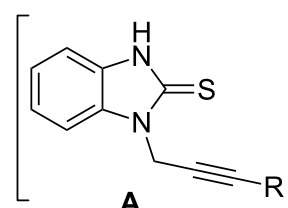

A
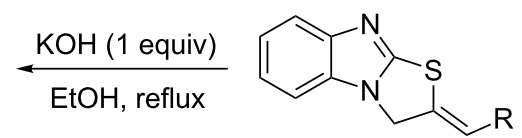

5a, $(59 \%)$

5b, $(73 \%)$

5c, $(69 \%)$

b)

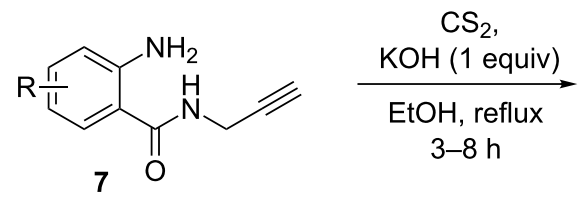<smiles>C=C1Cn2c(nc3c[R1]ccc3c2=O)S1</smiles>

8

7 examples (50-85\%)

(average yield: $71 \%$ )

$\mathrm{R}=\mathrm{H}, 4-\mathrm{NO}_{2}, 4-\mathrm{Cl}, 4,5-\mathrm{di}-\mathrm{OMe}, 5-\mathrm{Cl}, \mathrm{C}_{4} \mathrm{H}_{4}$ (3-amino-2-naphthoic acid)

Scheme 2: (a) One-pot synthesis of 2-benzylthiazolo[3,2-a]benzimidazoles 6 through a base-catalyzed cascade reaction of internal $N$-propargylamines 4 and $\mathrm{CS}_{2}$. (b) Synthesis of 2-methylene-thiazolo[2,3-b]quinazolinones 8 using 2-amino-propargylbenzamides 7 as substrates.

\section{From $\mathrm{N}$-propargylamines and isothiocyanates}

The first example of a synthesis of thiazole derivatives from $\mathrm{N}$-propargylamines and isothiocyanates was reported in 1964 by Easton et al. The authors obtained 2-iminothiazolidines $\mathbf{1 1}$ in good yields by the treatment of secondary $\alpha, \alpha$-disubstituted $\mathrm{N}$-propargylamines $\mathbf{9}$ with isothiocyanates $\mathbf{1 0}$ through a catalyst-free thiourea formation/intramolecular thia-Michael cyclization in ether (Scheme 3a). They also showed that the treatment of primary $\alpha, \alpha$-disubstituted $N$-propargylamines with isothiocyanates led to the corresponding $N$-propargylthioureas that converted to the cyclic forms upon standing for several days at room temperature [83]. Thirteen years later, Arya and co-workers applied this method for the synthesis of 3-thia-1azaspiro[4,5]decane ring systems [84]. In 1993, U. Urleb extended the scope of the reaction from isothiocyanates to heterocyclic isothiocyanates and some reported examples are shown in Scheme 3b [85].

This strategy was elegantly used by Sasmal and co-workers in the preparation of 2-aminothiazoles 17 from ethyl 4-aminobut2-ynoate salts $\mathbf{1 5}$ and isothiocyanates 16. Several bases and solvents were screened and the combination of $\mathrm{Et}_{3} \mathrm{~N}$ and THF at room temperature was found to be superior. Under the optimized conditions, the reaction tolerates both aryl and alkyl isothiocyanates $\mathbf{1 6}$ and gave the corresponding 2-aminothiazoles 17 in good to high yields (Scheme 4a). The authors further expanded the scope of $\mathrm{N}$-propargylamines to diethyl 3-aminoprop-1-ynylphosphonate salts $\mathbf{1 8}$ leading to 5-diethyl methylphosphonate-substituted 2-aminothiazoles 19 in good yields (Scheme 4b) [86].

An interesting approach towards the synthesis of 2-aminothiazole derivatives by treatment of $\mathrm{N}$-propargylamines with isothiocyanates in the presence of $p$-toluenesulfonic acid (PTSA) as catalyst under microwave irradiation was developed by Castagnolo et al. Following this route, several 4-substituted 5-methylthiazol-2-amines $\mathbf{2 2}$ were synthesized from terminal $N$-propargylamines 20 and isothiocyanates 21 in DMF at $160{ }^{\circ} \mathrm{C}$. Interestingly, when internal $N$-propargylamines were treated with 21, exclusively imidazolthiones $\mathbf{2 4}$ in yields ranging from 15 to $33 \%$ instead of the expected 2-aminothiazoles were obtained. The authors also found that with decreasing reaction temperature the yield of $\mathbf{2 2}$ decreased in favor of the thiazolines 23. Some reported examples are collected in Table 1 [87].

Recently, to develop an efficient protocol for the synthesis of 5-(iodomethylene)-3-methylthiazolidines 27 from $\mathrm{N}$-propargylamines, X. Zhou and co-workers have investigated the threecomponent halocyclization of $\mathrm{N}$-propargylamines $\mathbf{2 5}$, aryl isothiocyanates 26, and iodine in ethyl acetate. Excellent yields of desired products were observed (Scheme 5). The mechanism shown in Scheme 6 was proposed for this transformation and comprises the following key steps: (i) the reaction of $\mathrm{N}$-propargylamine $\mathbf{2 5}$ and isothiocyanate $\mathbf{2 6}$ forms the thiourea 
a)

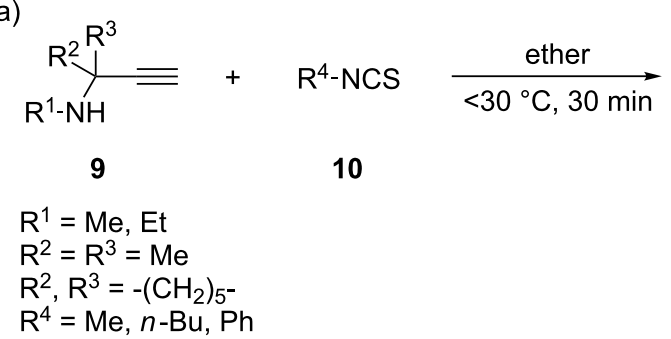

$\mathrm{R}^{4^{N}} \underbrace{\mathrm{N}}_{11} \overbrace{\mathrm{R}^{2}}^{\mathrm{S}} \mathrm{R}^{3}$

6 examples $\mathrm{R}^{2}, \mathrm{R}^{3}=-\left(\mathrm{CH}_{2}\right)_{5}$ $\mathrm{R}^{4}=\mathrm{Me}, n-\mathrm{Bu}, \mathrm{Ph}$

b)<smiles>COC(=O)c1sccc1N(S)S(C)(=O)=O</smiles>

$12 a$

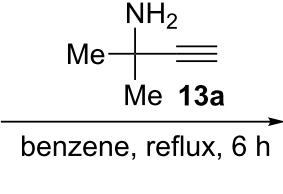

14aa, $(64 \%)$<smiles>COC(=O)c1sccc1N(S)S(=O)(=O)c1ccccc1</smiles>

12a

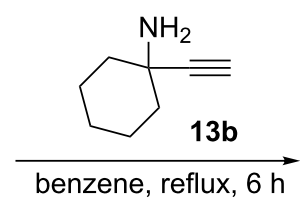

14ab, $(85 \%)$<smiles>C=C1SC(Nc2ccsc2C(C)=O)=NC1(C)C</smiles><smiles>CCOC(=O)c1cccnc1S(C)(=O)=O</smiles>

$12 b$

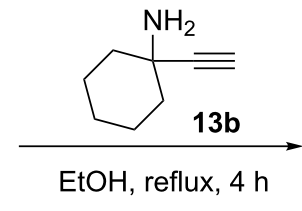

$\mathrm{EtOH}$, reflux, $4 \mathrm{~h}$<smiles>C=C1SC(Nc2ccsc2C(C)(C)C)=NC12CCCCC2</smiles><smiles>C=C1SC(Nc2ncccc2C(=O)OC)=NC12CCCCC2</smiles>

14bb, (53\%)

Scheme 3: (a) Synthesis of 2-iminothiazolidines 11 from N-propargylamines 9 and isothiocyanates 10. (b) Synthesis of 4,4-disubstituted-5-methylenethiazoles 14 using heterocyclic isothiocyanates 12 and $\alpha$, $\alpha$-disubstituted $N$-propargylamines 13 as substrates.

a)<smiles>[R]C(N)C#CC(=O)OCC</smiles>

$\mathrm{R}^{1}=\mathrm{H}, \mathrm{CH}_{2} \mathrm{CH}_{2} \mathrm{Ph}$

$\mathrm{R}^{2}=$ alkyl, aryl, benzyl, heteroaryl<smiles>[R]Nc1nc([R])c(COC([3H])=O)s1</smiles>

14 examples (65-93\%)

(average yield: $79 \%$ )

b)<smiles>[R10]N[As]</smiles>

$\mathrm{R}^{1}=\mathrm{H}, \mathrm{CH}_{2} \mathrm{CH}_{2} \mathrm{Ph}$

$\mathrm{R}^{2}=\mathrm{iPr}, \mathrm{Bn}, 4-\mathrm{Cl}-\mathrm{Ph}, 4-\mathrm{CO}_{2} \mathrm{Me}-\mathrm{Ph}, 3-$ pyridine<smiles>[R]Nc1nc([R])c(CP([O])(=O)OCC)s1</smiles>

7 examples (63-88\%) (average yield: $76 \%$ ) 
Table 1: Microwave-assisted domino reactions of $N$-propargylamines 20 with isothiocyanates 21 developed by Castagnolo.

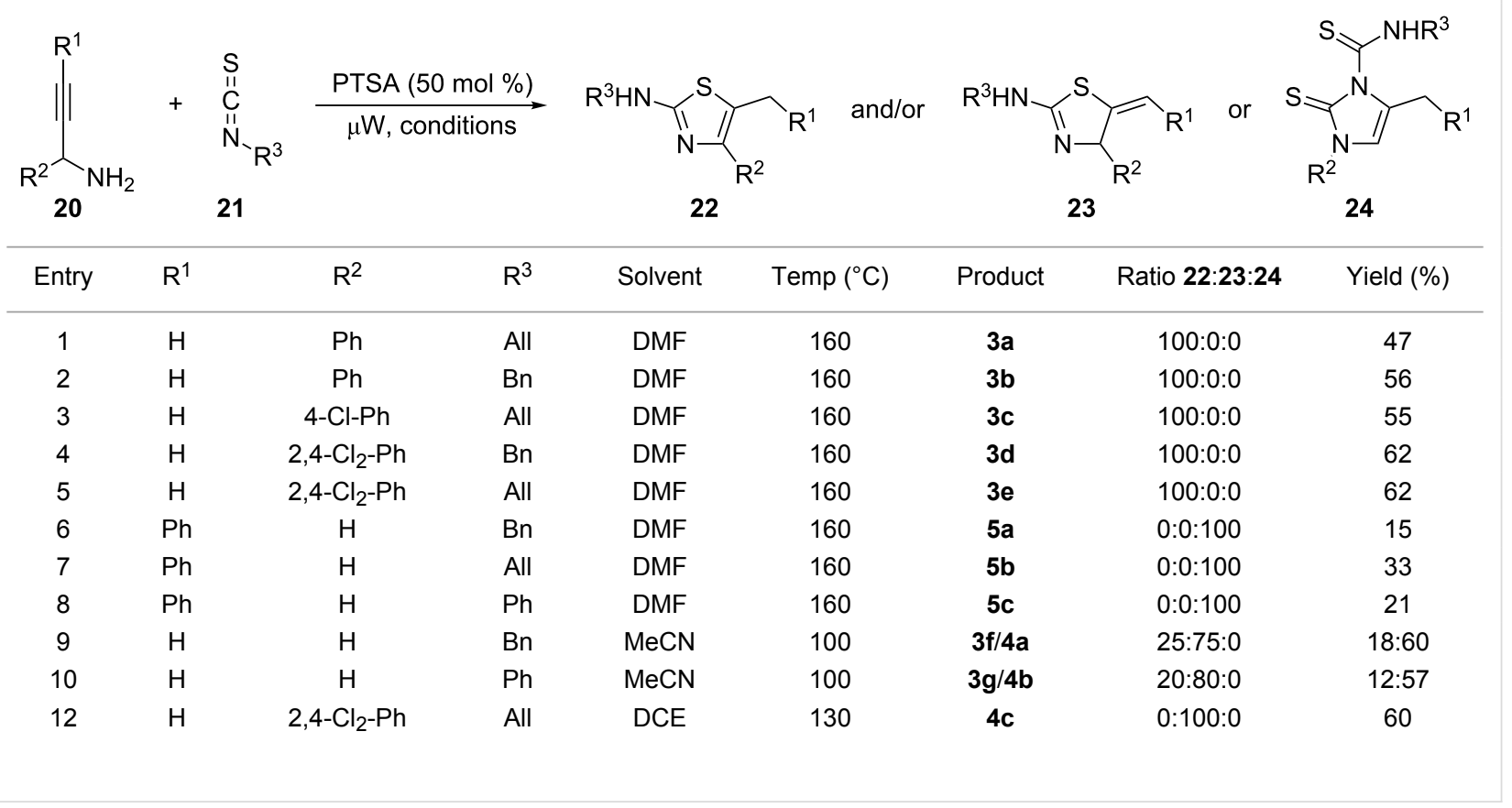

$\stackrel{\mathrm{NH}}{=}+\mathrm{R}-\mathrm{NCS}+\mathrm{I}_{2} \underset{\mathrm{rt}, 12 \mathrm{~h}}{\stackrel{\text { ethyl acetate }}{\longrightarrow}}$

25

$\mathrm{R}=\mathrm{Ph}, 4-\mathrm{Me}-\mathrm{Ph}, 4-\mathrm{Cl}-\mathrm{Ph}, 3-\mathrm{Cl}-\mathrm{Ph}$<smiles>[Z7]N1C/C(=C\I)SC1=[W]</smiles>

4 examples (86-99\%) (average yield: $95.5 \%$ )

Scheme 5: Synthesis of 5-(iodomethylene)-3-methylthiazolidines 27 described by Zhou.

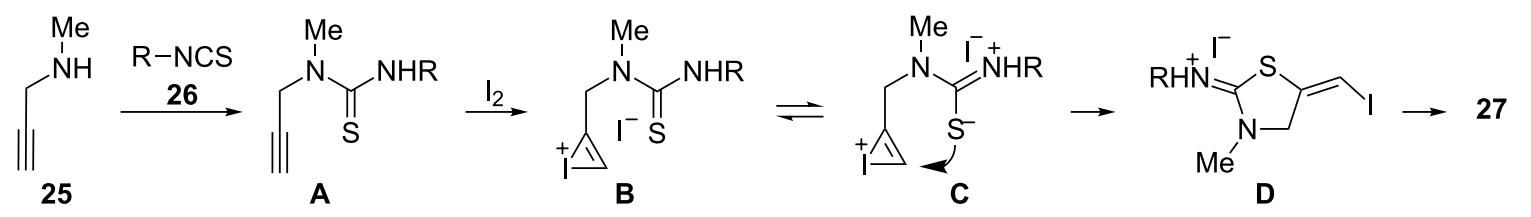

Scheme 6: Mechanism that accounts for the formation of 27.

intermediate $\mathbf{A}$, (ii) electrophilic addition of $\mathrm{I}_{2}$ to the alkyne moiety of this intermediate produces the iodonium intermediate $\mathbf{B}$, (iii) isomerization of iodonium $\mathbf{B}$ gives intermediate $\mathbf{C}$ and (iv) a sequential intramolecular cyclization and HI elimination of C finally affords thiazolidines 27 [88].

Seeking for a greener approach towards thiazolidines of type 30, the group of Clausen has proposed a base-catalyzed protocol using $t$ - $\mathrm{BuOH}$ in water at $20^{\circ} \mathrm{C}$ for a quite efficient cyclization between secondary $N$-propargylamines $\mathbf{2 8}$ and fluorescein isothiocyanate 29 (Scheme 7) [89].

More recently, Beauchemin and co-workers reported the syntheses of a series of multiply substituted thiazolidines 33 via the cyclization reaction of secondary $N$-propargylamines $\mathbf{3 2}$ with blocked $N$-isothiocyanate precursors 31. The desired 
$\stackrel{\mathrm{R}^{1}}{\mathrm{H}}=\mathrm{R}^{2}+$

28<smiles>O=C(O)c1cc(S(=O)(=O)[O-])ccc1-c1c2ccc(=O)cc-2oc2cc(O)ccc12</smiles>

29

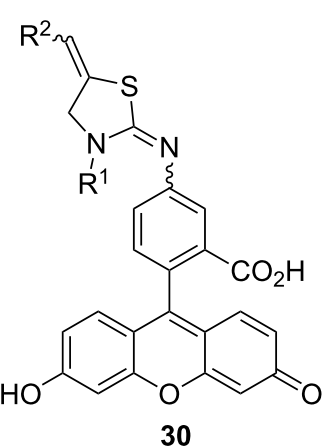

3 examples (78-82)

(average yield: $80 \%$ )

Scheme 7: Clausen's synthesis of fluorescein thiazolidines $\mathbf{3 0}$

$N$-isocyanates A are produced in situ upon heating or treatment with a base, in acetonitrile under microwave irradiation conditions (Scheme 8). The reaction tolerated a variety of functional groups such as fluoro, cyano, hydroxy, and methoxy, allowing a further derivatization of the products [90].

\section{From $N$-propargyl thioamides}

The first example of a thiazole synthesis from $N$-propargyl thioamides has been reported by Short and Ziegler in 1993. $\mathrm{N}$-Propargyl thiocarbamate $\mathbf{3 4}$ cyclized to disubstituted thiazole 35 through an addition-cycloelimination strategy by the treatment with sodium benzenesulfinate and $\mathrm{I}_{2}$ in ethyl acetate and water at $80^{\circ} \mathrm{C}$ (Scheme 9a) [91]. Later, the P. Wipf research team found that $N$-propargylamines 36 were converted to the corresponding vinylthiazolines $\mathbf{3 8}$ through the treatment with dithioic acids $\mathbf{3 7}$ in the presence of EDCI in dichloromethane. This transformation is believed to occur through a tandem coupling-cyclization reaction. The authors showed that the treatment of 38 with DBU at $0{ }^{\circ} \mathrm{C}$ provided thiazoles 39 in good yields (Scheme 9b) [92].

Along this line, Junjappa and co-workers reported an efficient route for the synthesis of 2-substituted 5-methylenethiazolidines 42 through the reaction of $\beta$-oxodithioesters 40 with $N$-propargylamine (41). The mechanism proposed by the authors to explain this reaction is based on the formation of $\beta$-oxo- $N$-propargyl thioamides $\mathbf{A}$ as intermediates, followed by their spontaneous ring closure. This reaction was run in refluxing ethanol and provided in all cases the desired thiazolidines $\mathbf{4 2}$ in high to excellent yields (Scheme 10) [93].<smiles>[R]/[R1]([H])=N/NC(=S)NC1CCCCC1</smiles>

33a, $(85 \%)$<smiles>C=C1CN(C)/C(=N/N=C/F)S1</smiles>

33g, $(76 \%)$

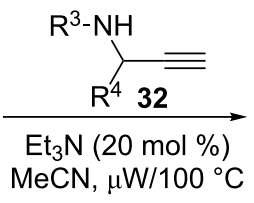<smiles>C=C1CN(C)/C(=N/N=C\C=[V])S1</smiles>

33b, $(60 \%)$<smiles>C=CCN1CC(=C)S/C1=N\N=C/C</smiles>

33h, (91\%)<smiles>[R1]C(=NN=C=S)C(C)C</smiles>

A

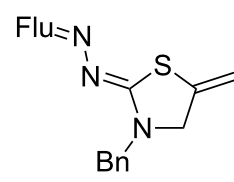

33c, $(68 \%)$<smiles>C=C1CN(c2ccccc2)/C(=N/N=C/C)S1</smiles>

33i, $(78 \%)$<smiles>[R]C([R])=NN=C1SC(=C)C([R])N1[R]</smiles>

33<smiles>C=C1S/C(=N\N=C/C)N(Cc2ccccc2)C1C</smiles>

33d, $(68 \%)$

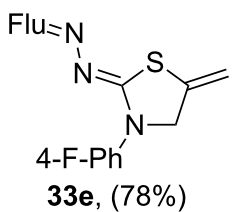<smiles>C=C1CN(CCCN)C(=NN=NC)S1</smiles>

33j, (74\%)<smiles>C=C1CN(CCO)C(=NN=CC)S1</smiles>

33k, (73\%)<smiles>C=C1CN([Pb](C)(C)C(=O)OC)C(=NN=CC)S1</smiles><smiles>O=[N+]([O-])c1ccc(I)cc1</smiles><smiles>C=C1CN(CCCCC)C(=NN=CCCCC)S1</smiles>

33I, $(79 \%)$

Scheme 8: Synthesis of multiply substituted thiazolidines 33 from $\mathrm{N}$-propargylamines $\mathbf{3 2}$ and blocked $\mathrm{N}$-isothiocyanate precursors $\mathbf{3 1}$. 


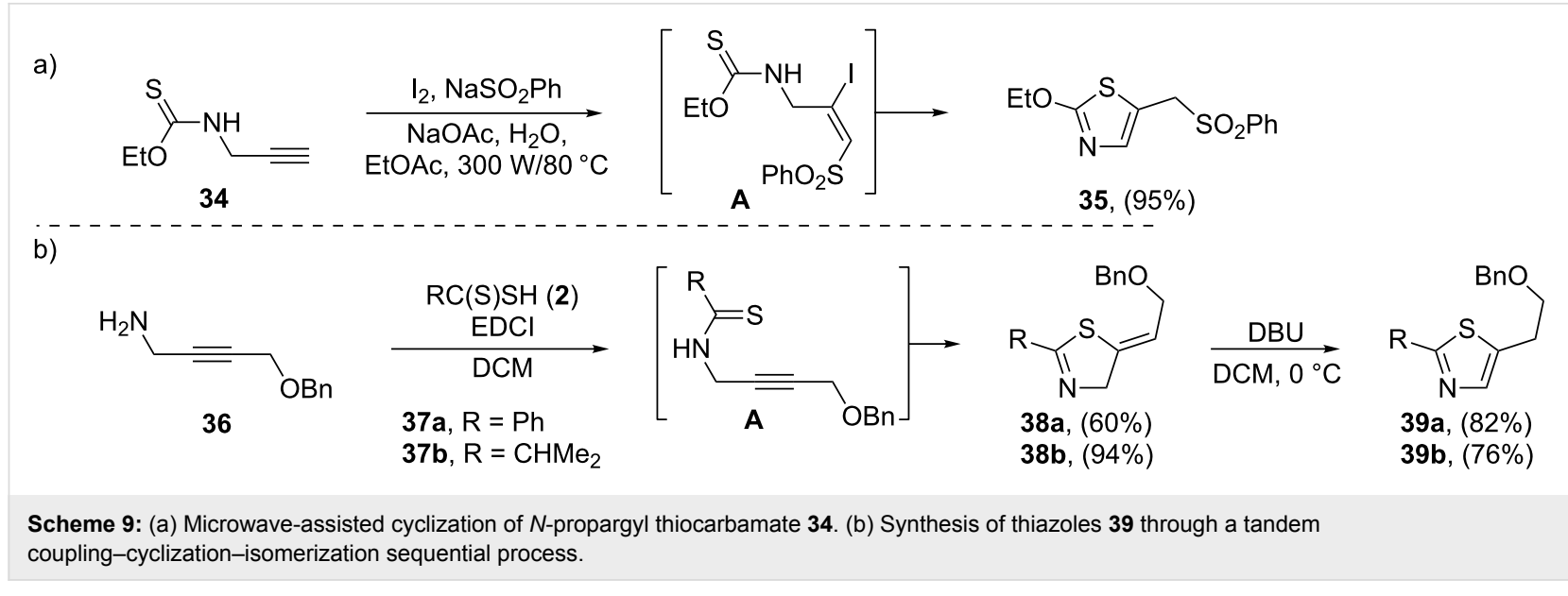

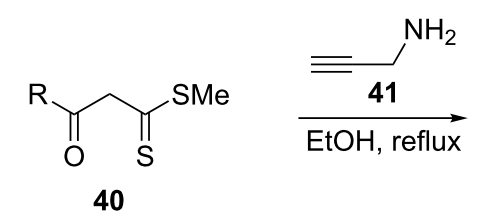

$\mathrm{R}=\mathrm{Me}, \mathrm{Ph}, 4-\mathrm{MeOC}_{2} \mathrm{H}_{4}$, 2-thiophenyl

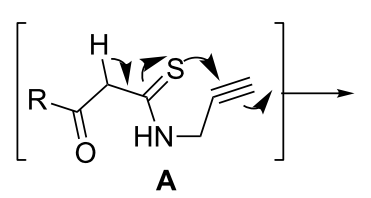

A<smiles>[R]C(=O)C=C1NCC(=C)S1</smiles>

4 examples (86-94\%) (average yield: $90 \%$ )<smiles>[R1]C1CCC2=C(CCCC2)C1=O</smiles>

$\mathrm{R}^{1}=\mathrm{H}, \mathrm{OMe}$ $n=1,2$

\section{$\underset{\mathrm{EtOH}, \text { reflux }}{\mathbf{4 1}}$}<smiles>[R1][Y]1CCC2=C(CC/C(=C3/NCC(=C)S3)C2=O)CC1[R10]</smiles>

4 examples (83-93\%)

(average yield: $89 \%$ )

Scheme 10: Synthesis of thiazolidines $42\left(42^{\prime}\right)$ from the reaction of $\beta$-oxodithioesters $40\left(40^{\prime}\right)$ with $N$-propargylamine (41) through an $N$-propargylthioamide intermediate $\mathbf{A}$.

In 2009, Yarovenko and co-workers developed the synthesis of 5-(dibromomethyl)thiazole derivatives $\mathbf{4 4}$ by treatment of $\mathrm{N}$-propargyl thioamides $\mathbf{4 3}$ with bromine in an ionic liquid (1-butyl-3-methylimidazolium hexafluorophosphate). Mechanistically, the reaction involves: i) bromination of triple bond of thioamide 43 which resulted in a bridged bromonium ion intermediate $\mathbf{A}$; ii) regioselective 5-exo-dig cyclization of intermediate $\mathbf{A}$ to give dihydrothiazole $\mathbf{B}$; and iii) addition of a second bromine to the alkene moiety in intermediate $\mathbf{B}$ to provide the corresponding thiazole 44 (Scheme 11) [94].

Recently, Alhalib and Moran reported two examples for the preparation of fully substituted dihydrothiazoles $\mathbf{4 6}$ through the treatment of $\mathrm{N}$-propargylamides $\mathbf{4 5}$ with Lawesson's reagent in toluene. It is suggested that the $N$-(propargyl)thioamide intermediate $\mathbf{A}$ is initially formed, followed by a facile 5-exo-dig cyclization process to give the final products $\mathbf{4 6}$ in moderate yields (Scheme 12) [95].
An important study on 2,5-disubstituted thiazoles 49 was carried out by Sasmal, Sridhar, and Iqbal. The authors converted silyl-protected $N$-propargylamines 47 into thiazoles 49 by their treatment with benzotriazolylthiones 48 in a $\mathrm{THF} / \mathrm{MeOH} / \mathrm{Et}_{3} \mathrm{~N}$ system (Scheme 13). The proposed mechanism for the reaction starts with the generation of the $N$-(propargyl)thioamide intermediates A through a thioacylation of $\mathrm{N}$-propargylamine $\mathbf{4 7}$ with benzotriazolylthione 48 . Then $\mathrm{N}$-desilylation of $\mathbf{A}$ furnishes intermediate $\mathbf{B}$ which undergoes a base-promoted cyclization to give the intermediate C. Finally, the isomerization of $\mathbf{C}$ affords the observed products $\mathbf{4 9}$ (Scheme 14) [96].

In 2011, X. Meng and S. Kim reported an example of thiazolidine preparation through a Mo-catalyzed 5-exo-dig cyclization of the $\mathrm{N}$-propargylthiocarbamate $\mathbf{5 0}$ in toluene under irradiation at $350 \mathrm{~nm}$. As shown in Scheme 15 the target 2-phenoxysubstituted thiazolidine 51 was obtained in a yield of 54\% 

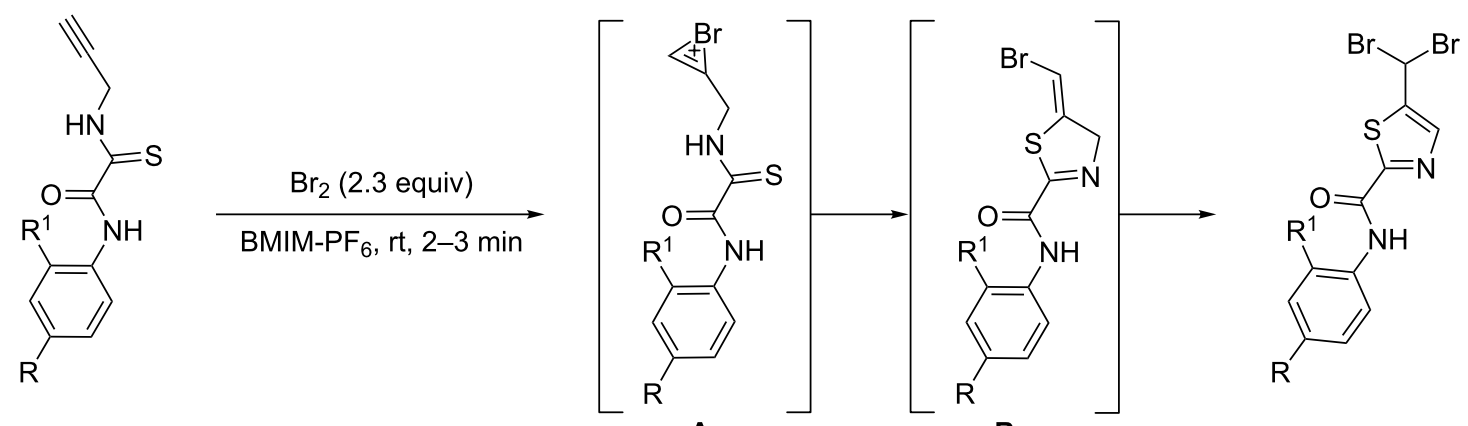

43a, $\mathrm{R}=\mathrm{H}, \mathrm{R}^{1}=\mathrm{NO}_{2}$

A

B

44a, $(83 \%)$

44b, $(86 \%)$

43c, $\mathrm{R}=\mathrm{Me}, \mathrm{R}^{1}=\mathrm{NO}_{2}$

43d, $\mathrm{R}=\mathrm{NO}_{2}, \mathrm{R}^{1}=\mathrm{H}$

BMIM-PF 6 = 1-butyl-3-methylimidazolium hexafluorophosphate

44c, $(87 \%)$

44d, $(85 \%)$

Scheme 11: Synthesis of 5-(dibromomethyl)thiazoles 44 via halocyclization of $N$-propargylamines 43 described by Yarovenko.<smiles>[R]C(=O)NC(C)(C)C#C</smiles>

45a, $R=P h$

45b, $\mathrm{R}=4-\mathrm{Cl}-\mathrm{Ph}$

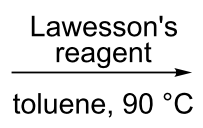

toluene, $90^{\circ} \mathrm{C}$

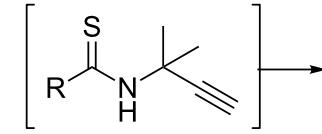

A

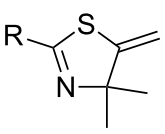

46a, (53\%)

$46 b,(63 \%)$

Scheme 12: Synthesis of dihydrothiazoles 46 through the treatment of $N$-propargylamides 45 with Lawesson's reagent.

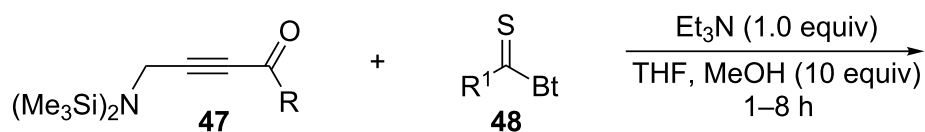

$\mathrm{R}=\mathrm{OEt}, \mathrm{NMe}_{2}$

$\mathrm{R}^{1}=4-\mathrm{Cl}-\mathrm{Ph}$, tolyl, $n-\mathrm{Pr}, t-\mathrm{Bu}$, SMe, SPh, OEt,

$\mathrm{OBn}, \mathrm{OPh}, 4-\mathrm{OMe}-\mathrm{Ph}, \mathrm{HN}($ allyl), $\mathrm{Bt}$<smiles>[R]Cc1cnc([As])s1</smiles>

49

14 examples $(26-93 \%)$

(average yield: $73 \%$ )

Scheme 13: Synthesis of thiazoles 49 by treatment of silyl-protected $N$-propargylamines 47 with benzotriazolylthiones 48 .
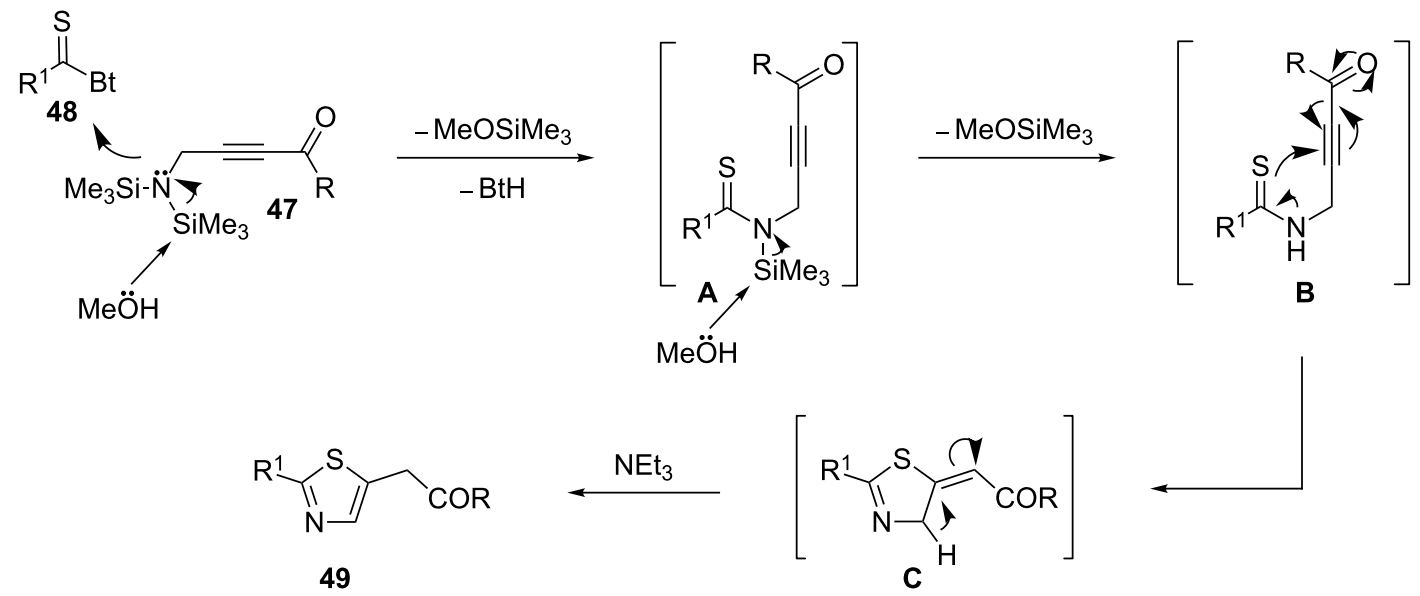

Scheme 14: Mechanism proposed to explain the synthesis of 2,5-disubstituted thiazoles 49 developed by Sasmal. 


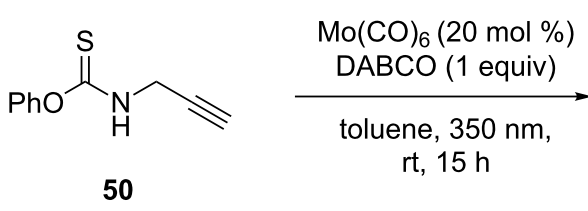

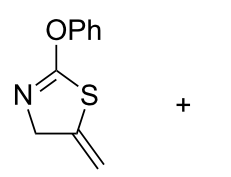

$51,(54 \%)$<smiles>C1=CSC(Oc2ccccc2)=NC1</smiles>

52, $(36 \%)$

Scheme 15: Mo-catalyzed cyclization of $\mathrm{N}$-propargylthiocarbamate $\mathbf{5 0}$.

along with the product originating from a 6-endo-dig cyclization [97].

Recently, Foroumadi and co-workers studied the possibility of synthesizing thiazole derivatives from $N$-propargylthioureas through a regioselective 5-exo-dig cyclization-proton transfer-isomerization sequential process. They found that the easily available $N$-(propargylcarbamothioyl)amides $\mathbf{5 3}$ in the presence of 1,4-diazabicyclo[2.2.2] octane (DABCO) as the base in refluxing ethanol, rapidly cyclized and produced the corresponding dihydrothiazol-2-ylamides $\mathbf{5 4}$ in good yields (Scheme 16a). The mechanism for this cyclization as proposed by the authors is depicted in Scheme 16b [98].

Following this work, the Čikotienè group studied the metal-free halogen, chalcogen, or oxocarbenium ion-mediated cyclization of a series of $\mathrm{N}$-propargylthioureas 55 (Table 2). Some important information of the reactions are listed below: (1) iodinemediated cyclizations of terminal $\mathrm{N}$-propargylthioureas $\mathbf{5 5}$ gave exclusively 4,5-dihydrothiazoles $\mathbf{5 7}$ through a 5-exo-dig cycli- zation, whereas internal $N$-propargylthioureas $\mathbf{5 5}$ under the same reaction conditions gave a mixture of $4 H-1,3$-thiazines $\mathbf{5 6}$ and 4,5-dihydrothiazoles $\mathbf{5 7}$. The mechanistic course of this reaction sequence is shown in Scheme 17 and involves the initial formation of the charge-transfer complex $\mathbf{A}$ between the iodonium ion and the triple bond. The 5-exo-dig cyclization of this intermediate gives rise to 4,5-dihydrothiazoles and the competing 6-endo-dig ring-closing process affords $4 H$-1,3thiazines after conversion of the charge-transfer complex into the ring-opened iodovinyl $\mathbf{B}$ or bridged iodirenium $\mathbf{C}$ ions; (2) bromine-mediated cyclizations of both electron-poor and electron-rich $N$-propargylthioureas 55 gave exclusively 4,5dihydrothiazoles $\mathbf{5 7}$ in moderate to good yields; (3) phenyl hypochloroselenoite-mediated cyclizations of terminal $\mathrm{N}$-propargylthioureas $\mathbf{5 5}$ underwent a regioselective 5-exo-dig cyclization giving the corresponding 4,5-dihydrothiazoles 57 in moderate yields. On the other hand internal $N$-propargylamines 55 under the same reaction conditions gave a mixture of $\mathbf{5 7}$ and 56; (4) arylideneoxonium ion-mediated cyclization of internal $\mathrm{N}$-propargylamines $\mathbf{5 5}$ afforded exclusively the corresponding

a)<smiles>[R]C(=O)NC(=S)NCC#C</smiles>

53

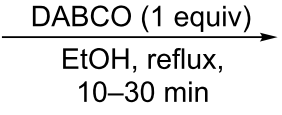

$\mathrm{R}=4-\mathrm{MeOC}_{6} \mathrm{H}_{4}, 4-\mathrm{ClC}_{6} \mathrm{H}_{4}, 4-\mathrm{NO}_{2} \mathrm{C}_{6} \mathrm{H}_{4}, 3-\mathrm{MeC}_{6} \mathrm{H}_{4}, 3-\mathrm{ClC}_{6} \mathrm{H}_{4}$, 3- $\mathrm{NO}_{2} \mathrm{C}_{6} \mathrm{H}_{4}, 2-\mathrm{MeC}_{6} \mathrm{H}_{4}, 2-\mathrm{ClC}_{6} \mathrm{H}_{4}$, 2-furyl, 2-thiophenyl<smiles>[R]C(=O)NC1=NCC(=C)S1</smiles>

54

10 examples (65-80\%)

(average yield: $74 \%$ )

b)

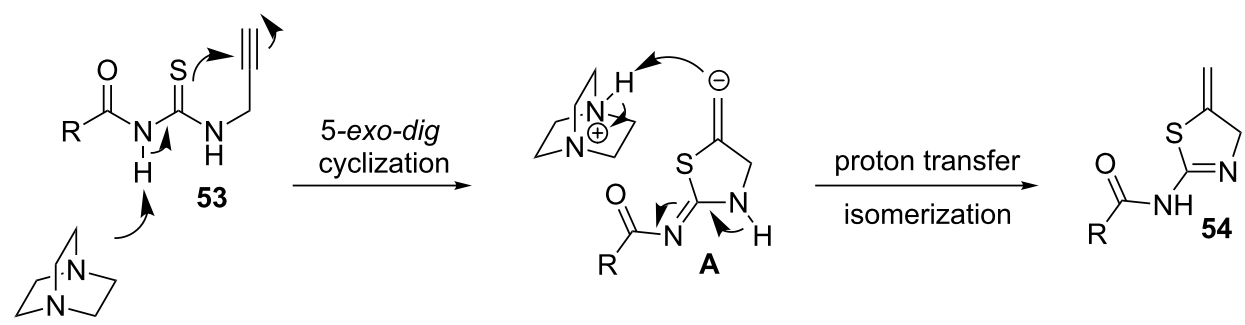


Table 2: Electrophile-mediated cyclization of N-propargylthioureas 55.

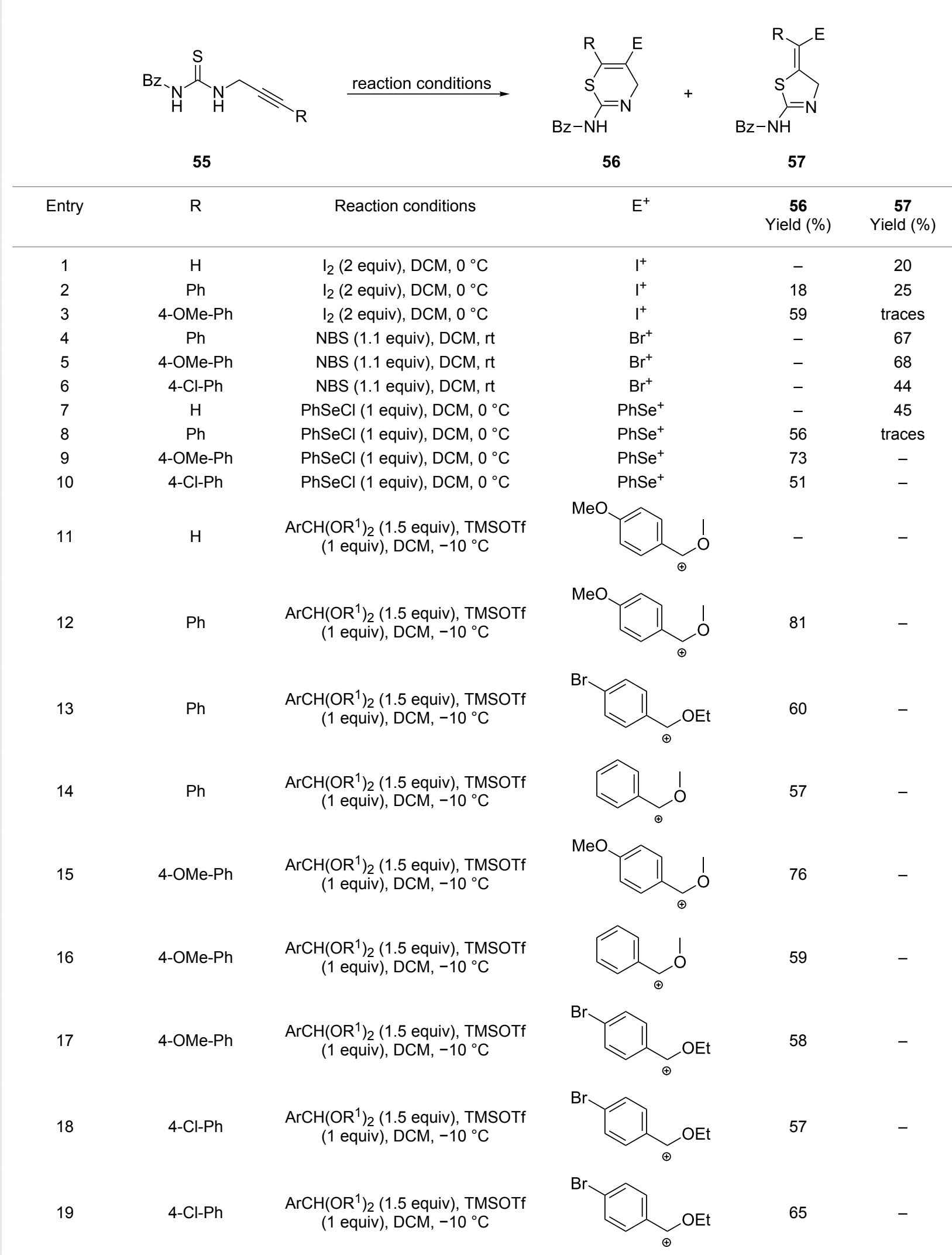


4H-1,3-thiazines 56 in good yields. However, terminal $\mathrm{N}$-propargylamines failed to participate in this reaction [99].

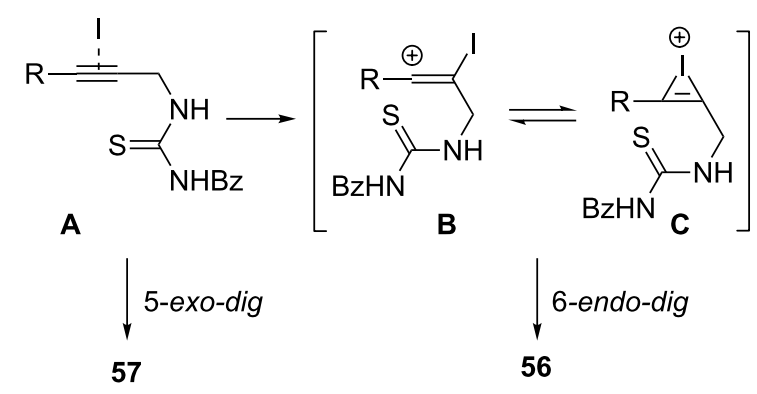

Scheme 17: Proposed mechanism for the generation of the iodinesubstituted 4H-1,3-thiazines $\mathbf{5 6}$ and 4,5-dihydrothiazoles $\mathbf{5 7}$.

\section{Miscellaneous}

Recently, Stevens and co-workers reported a robust protocol towards dihydrothiazoles through an $\mathrm{Au}(\mathrm{III})$-catalyzed intramolecular cyclization of the corresponding dithiocarboimidates. Thus, the corresponding 5-alkylidene-dihydrothiazoles $\mathbf{5 8}$ were synthesized in good to excellent yields from $\mathrm{N}$-(propargyldithiocarbo)imidates 57 through a 5-exo-dig cyclization followed by a thio-Claisen-type rearrangement with $\mathrm{AuCl}_{3}$ as the catalyst in dichloromethane (Scheme 18). It is worth mentioning that the required $\mathrm{N}$-(propargyldithiocarbo)imidates were easily prepared in high yields through a condensation of commercially available and cheap $\mathrm{N}$-propargylamine, allyl bromide, and carbon disulfide [100].

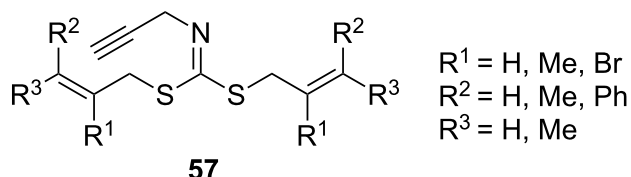

57

$$
\mathrm{AuCl}_{3}(5 \mathrm{~mol} \%)
$$$$
\text { DCM, } 20^{\circ} \mathrm{C}
$$<smiles>[R]C(=C)C([R1])([R])/C=C\C1CN=C(SCC([R])=C([R])[R])S1</smiles>

6 examples (74-95\%)

(average yield: $88 \%$ )

Scheme 18: Au(III)-catalyzed synthesis of 5-alkylidenedihydrothiazoles $\mathbf{5 8}$ developed by Stevens.

\section{Conclusion}

Much work has been carried out during the past decade and has demonstrated that $N$-propargylamines are one of the most useful and versatile precursors in the synthesis of various nitrogen heterocycles and complex natural products. In this regard, recently an impressive increase in the number of publications on the preparation of thiazoles and their hydrogenated analogues through inter- and intramolecular cyclization of $\mathrm{N}$-propargylamine derivatives appeared in the literature. In this review we discussed the most representative and interesting reports on this emerging field. As illustrated, the processes provided the title compounds in good yields with fewer steps and higher atom economy than previously reported examples. We hope that this review will encourage synthetic organic chemists to employ these valuable methodologies to the synthesis of important new thiazole derivatives.

\section{References}

1. Villars, V.; Jones, T. C. Clin. Exp. Dermatol. 1989, 14, 124-127. doi:10.1111/j.1365-2230.1989.tb00908.x.

2. Kagawa, S. Clin. Exp. Dermatol. 1989, 14, 114-115. doi:10.1111/j.1365-2230.1989.tb00905.x

3. Tamura, T.; Asahara, M.; Yamamoto, M.; Yamaura, M.; Matsumura, M.; Goto, K.; Rezaei-Matehkolaei, A.; Mirhendi, H.; Makimura, M.; Makimura, K. Microbiol. Immunol. 2014, 58, 1-8. doi:10.1111/1348-0421.12109

4. Borelli, C.; Schaller, M.; Niewerth, M.; Nocker, K.; Baasner, B.; Berg, D.; Tiemann, R.; Tietjen, K.; Fugmann, B.; Lang-Fugmann, S.; Korting, H. C. Chemotherapy 2008, 54, 245-259. doi:10.1159/000142334

5. Takano, Y.; Hase-Aoki, K.; Horiuchi, H.; Zhao, L.; Kasahara, Y.; Kondo, S.; Becker, M. A. Life Sci. 2005, 76, 1835-1847. doi:10.1016/j.lfs.2004.10.031

6. Sánchez-Lozada, L. G.; Tapia, E.; Soto, V.; Ávila-Casado, C.; Franco, M.; Zhao, L.; Johnson, R. J. Nephrol., Dial., Transplant. 2008, 23, 1179-1185. doi:10.1093/ndt/gfm783

7. Kataoka, H.; Yang, K.; Rock, K. L. Eur. J. Pharmacol. 2015, 746, 174-179. doi:10.1016/j.ejphar.2014.11.013

8. Molla, A.; Korneyeva, M.; Gao, Q.; Vasavanonda, S.; Schipper, P. J.; Mo, H.-M.; Markowitz, M.; Chernyavskiy, T.; Niu, P.; Lyons, N.; Hsu, A.; Granneman, G. R.; Ho, D. D.; Boucher, C. A. B.; Leonard, J. M.; Norbeck, D. W.; Kempf, D. J. Nat. Med. 1996, 2, 760-766. doi:10.1038/nm0796-760

9. Boffito, M.; Jackson, A.; Pozniak, A.; Giraudon, M.; Kulkarni, R.; Abelardo, M. C.; Patel, I. H.; Morcos, P. N. Drugs R\&D 2015, 15 , 141-153. doi:10.1007/s40268-015-0087-7

10. Vitale, M.; Zamai, L.; Falcieri, E.; Zauli, G.; Gobbi, P.; Santi, S.; Cinti, C.; Weber, G. Cytometry 1997, 30, 61-66. doi:10.1002/(SICI)1097-0320(19970215)30:1<61::AID-CYTO9>3.0.C O;2-I

11. Pankiewicz, K. W. Pharmacol. Ther. 1997, 76, 89-100. doi:10.1016/S0163-7258(97)00092-2

12. Savić, D.; Stanković, T.; Lavrnja, I.; Podolski-Renić, A.; Banković, J.; Peković, S.; Stojiljković, M.; Rakić, L.; Ruždijić, S.; Pešić, M. Mol. Inhibit. Target. Ther. 2015, 1, 3-14. doi:10.1515/motth-2015-0002 
13. Weber, G.; Natsumeda, Y.; Lui, M. S.; Faderan, M. A.; Liepnieks, J. J.; Elliott, W. L. Adv. Enzyme Regul. 1984, 22, 69-93. doi:10.1016/0065-2571(84)90009-8

14. https://pixabay.com/en/syringe-pill-bottle-morphine-small-1884784/. (accessed Feb 14, 2017).

15. Jin, Z. J. Nat. Prod. 2016, 33, 1268-1318. doi:10.1039/c6np00067c

16. Ramu, E.; Rao, B. V. Tetrahedron: Asymmetry 2009, 20, 2201-2204. doi:10.1016/j.tetasy.2009.09.003

17. Le Bozec, L.; Moody, C. J. Aust. J. Chem. 2009, 62, 639-647. doi:10.1071/CH09126

18. Davyt, D.; Serra, G. Mar. Drugs 2010, 8, 2755-2780. doi:10.3390/md8112755

19. https://pixabay.com/en/nudibranch-snorkeling-diving-scuba-274937/. (accessed Feb 14, 2017).

20. https://pixabay.com/en/pine-cones-pine-nuts-tap-forest-820759/ (accessed Feb 14, 2017).

21. https://pixabay.com/en/glow-worm-glowworm-bug-firefly-147679/. (accessed Feb 14, 2017).

22. https://pixabay.com/en/cranberries-berries-red-berry-112151/. (accessed Feb 14, 2017).

23. https://pixabay.com/en/sea-slugs-pests-snail-plague-nature-590491/. (accessed Feb 14, 2017).

24. https://pixabay.com/en/sponge-beach-sea-water-sun-summer-62721/. (accessed Feb 14, 2017).

25. Harikrishna, N.; Isloor, A. M.; Ananda, K.; Obaid, A.; Fun, H.-K. RSC Adv. 2015, 5, 43648-43659. doi:10.1039/C5RA04995D

26. Zagade, A. A.; Senthilkumar, G. P. Pharma Chem. 2011, 3, 523-537.

27. Smirnova, N. G.; Zavarzin, I. V.; Krayushkin, M. M. Chem. Heterocycl. Compd. 2006, 42, 144-165. doi:10.1007/s10593-006-0064-8

28. Halimehjani, A. Z.; Hasani, L.; Alaei, M. A.; Saidi, M. R. Tetrahedron Lett. 2016, 57, 883-886. doi:10.1016/j.tetlet.2016.01.045

29. Chen, B.; Guo, S.; Guo, X.; Zhang, G.; Yu, Y. Org. Lett. 2015, 17, 4698-4701. doi:10.1021/acs.orglett.5b02152

30. Miura, T.; Funakoshi, Y.; Fujimoto, Y.; Nakahashi, J.; Murakami, M. Org. Lett. 2015, 17, 2454-2457. doi:10.1021/acs.orglett.5b00960

31. Kumar, S. V.; Parameshwarappa, G.; Ila, H. J. Org. Chem. 2013, 78, 7362-7369. doi:10.1021/jo401208u

32. Maltsev, O. V.; Walter, V.; Brandl, M. J.; Hintermann, L. Synthesis 2013, 45, 2763-2767. doi:10.1055/s-0033-1339492

33. Chhabria, M. T.; Patel, S.; Modi, P.; Brahmkshatriya, P. S. Curr. Top. Med. Chem. 2016, 16, 2841-2862. doi:10.2174/1568026616666160506130731

34. Hantzsch, A.; Weber, J. H. Ber. Dtsch. Chem. Ges. 1887, 20, 3118-3132. doi:10.1002/cber.188702002200

35. Bramley, S. E.; Dupplin, V.; Goberdhan, D. G. C.; Meakins, G. D. J. Chem. Soc., Perkin Trans. 1 1987, 639-643. doi:10.1039/P19870000639

36. Aguilar, E.; Meyers, A. I. Tetrahedron Lett. 1994, 35, 2473-2476. doi:10.1016/S0040-4039(00)77147-4

37. Prakash, R.; Kumar, A.; Aggarwal, R.; Prakash, O.; Singh, S. P. Synth. Commun. 2007, 37, 2501-2505. doi:10.1080/00397910701462476

38. Merritt, E. A.; Bagley, M. C. Synthesis 2007, 3535-3541. doi:10.1055/s-2007-990851

39. Guernon, J. M.; Wu, Y.-J. Tetrahedron Lett. 2011, 52, 3633-3635. doi:10.1016/j.tetlet.2011.05.028

40. Chidananda, N.; Poojary, B.; Sumangala, V.; Kumari, N. S. Med. Chem. Res. 2014, 23, 3979-3997. doi:10.1007/s00044-014-0975-3
41. Kamila, S.; Mendoza, K.; Biehl, E. R. Tetrahedron Lett. 2012, 53, 4921-4924. doi:10.1016/j.tetlet.2012.06.116

42. Gu, C.; Zhai, J.; Jiang, J.; Liu, H.; Wang, L.; Zhu, D.; Ji, Y. Chin. J. Chem. 2014, 32, 179-190. doi:10.1002/cjoc.201300878

43. Ding, C.; Zhang, Y.; Chen, H.; Yang, Z.; Wild, C.; Chu, L.; Liu, H.; Shen, Q.; Zhou, J. J. Med. Chem. 2013, 56, 5048-5058. doi:10.1021/jm400367n

44. Gaumont, A.-C.; Gulea, M.; Levillain, J. Chem. Rev. 2009, 109, 1371-1401. doi:10.1021/cr800189z

45. Tan, K. C.; Wakimoto, T.; Takada, K.; Ohtsuki, T.; Uchiyama, N.; Goda, Y.; Abe, I. J. Nat. Prod. 2013, 76, 1388-1391. doi:10.1021/np400404r

46. Budovská, M.; Kutschy, P.; Kožár, T.; Gondová, T.; Petrovaj, J. Tetrahedron 2013, 69, 1092-1104. doi:10.1016/j.tet.2012.11.067

47. Segade, Y.; Montaos, M. A.; Rodríguez, J.; Jiménez, C. Org. Lett. 2014, 16, 5820-5823. doi:10.1021/ol502958u

48. Pedras, M. S. C.; Sarma-Mamillapalle, V. K. Bioorg. Med. Chem. Lett. 2012, 20, 3991-3996. doi:10.1016/j.bmc.2012.05.020

49. Kreutzer, M. F.; Kage, H.; Herrmann, J.; Pauly, J.; Hermenau, R.; Müller, R.; Hoffmeister, D.; Nett, M. Org. Biomol. Chem. 2014, 12, 113-118. doi:10.1039/c3ob41839a

50. Aeluri, M.; Dasari, B.; Arya, P. Org. Lett. 2015, 17, 472-475. doi:10.1021/ol503465p

51. Han, F. S.; Osajima, H.; Cheung, M.; Tokuyama, H.; Fukuyama, T. Chem. - Eur. J. 2007, 13, 3026-3038. doi:10.1002/chem.200601446

52. Sondhi, S. M.; Rani, R.; Gupta, P. P.; Agrawal, S. K.; Saxena, A. K. Mol. Diversity 2009, 13, 357-366. doi:10.1007/s11030-009-9125-0

53. Havrylyuk, D.; Kovach, N.; Zimenkovsky, B.; Vasylenko, O.; Lesyk, R. Arch. Pharm. 2011, 344, 514-522. doi:10.1002/ardp.201100055

54. Meleddu, R.; Distinto, S.; Corona, A.; Tramontano, E.; Bianco, G.; Melis, C.; Cottiglia, F.; Maccioni, E. J. Enzyme Inhib. Med. Chem. 2016, 32, 130-136. doi:10.1080/14756366.2016.1238366

55. Lu, Z.; Harper, M. K.; Pond, C. D.; Barrows, L. R.; Ireland, C. M.; Van Wagoner, R. M. J. Nat. Prod. 2012, 75, 1436-1440. doi:10.1021/np300270p

56. Kim, E.-A.; Choi, J.; Han, A. R.; Choi, S. Y.; Hahn, H.-G.; Cho, S.-W. NeuroToxicology 2013, 38, 106-114. doi:10.1016/j.neuro.2013.07.001

57. Bonde, C. G.; Gaikwad, N. J. Bioorg. Med. Chem. 2004, 12, 2151-2161. doi:10.1016/j.bmc.2004.02.024

58. Bondock, S.; Khalifa, W.; Fadda, A. A. Eur. J. Med. Chem. 2007, 42, 948-954. doi:10.1016/j.ejmech.2006.12.025

59. Altıntop, M. D.; Kaplancıklı, Z. A.; Çiftçi, G. A.; Demirel, R. Eur. J. Med. Chem. 2014, 74, 264-277. doi:10.1016/j.ejmech.2013.12.060

60. Zipperer, A.; Konnerth, M. C.; Laux, C.; Berscheid, A.; Janek, D.; Weidenmaier, C.; Burian, M.; Schilling, N. A.; Slavetinsky, C.; Marschal, M.; Willmann, M.; Kalbacher, H.; Schittek, B.; Brötz-Oesterhelt, H.; Grond, S.; Peschel, A.; Krismer, B. Nature 2016, 535, 511-516. doi:10.1038/nature18634

61. Faine, S.; Harper, M. Antimicrob. Agents Chemother. 1973, 3, 15-18. doi:10.1128/AAC.3.1.15

62. Garrod, L. Br. Med. J. 1960, 1, 527-529. doi:10.1136/bmj.1.5172.527

63. Bodin, N.-O.; Ekström, B.; Forsgren, U.; Jalar, L.-P.; Magni, L.; Ramsay, C.-H.; Sjöberg, B. Antimicrob. Agents Chemother. 1975, 8, 518-525. doi:10.1128/AAC.8.5.518

64. Akova, M. Clin. Microbiol. Infect. 2008, 14, 185-188. doi:10.1111/j.1469-0691.2007.01847.x

65. Vessally, E. RSC Adv. 2016, 6, 18619-18631. doi:10.1039/C5RA20706A 
66. Vessally, E.; Hosseinian, A.; Edjlali, L.; Bekhradnia, A.; Esrafili, M. D. RSC Adv. 2016, 6, 71662-71675. doi:10.1039/C6RA08720E

67. Vessally, E.; Edjlali, L.; Hosseinian, A.; Bekhradnia, A.; Esrafili, M. D. RSC Adv. 2016, 6, 49730-49746. doi:10.1039/C6RA05221E

68. Vessally, E.; Hosseinian, A.; Bekhradnia, A.; Esrafili, M. D. Curr. Org. Synth. 2017, 14, 557-567. doi:10.2174/1570179413666160818144816

69. Vessally, E.; Hosseinian, A.; Edjlali, L.; Bekhradnia, A.; Esrafili, M. D. RSC Adv. 2016, 6, 99781-99793. doi:10.1039/C6RA20718A

70. Vessally, E.; Soleimani-Amiri, S.; Hosseinian, A.; Edjlali, L.; Bekhradnia, A. RSC Adv. 2017, 7, 7079-7091. doi:10.1039/c6ra25816f

71. Arshadi, S.; Vessally, E.; Edjlali, L.; Ghorbani-Kalhor, E.; Hosseinzadeh-Khanmiri, R. RSC Adv. 2017, 7, 13198-13211. doi:10.1039/c7ra00746a

72. Vessally, E.; Hosseinzadeh-Khanmiri, R.; Ghorbani-Kalhor, E.; Es'haghi, M.; Bekhradnia, A. RSC Adv. 2017, 7, 19061-19072. doi:10.1039/c7ra01371j

73. Vessally, E.; Abdoli, M. J. Iran. Chem. Soc. 2016, 13, 1235-1256. doi:10.1007/s13738-016-0838-6

74. Vessally, E.; Saeidian, H.; Hosseinian, A.; Edjlali, L.; Bekhradnia, A. Curr. Org. Chem. 2017, 21, 249-271. doi:10.2174/1385272820666161018150925

75. Batty, J. W.; Weedon, B. C. L. J. Chem. Soc. 1949, 786-789. doi:10.1039/JR9490000786

76. Hanefeld, W.; Bercin, E. Liebigs Ann. Chem. 1985, 58-64. doi:10.1002/jlac.198519850107

77. Shi, M.; Shen, Y.-M. Heteroat. Chem. 2001, 12, 610-616. doi:10.1002/hc.1092

78. Shi, M.; Shen, Y.-M. J. Org. Chem. 2002, 67, 16-21. doi:10.1021/jo0014966

79. Liu, A.; He, L.; Peng, S.; Pan, Z.; Wang, J.; Gao, J. Sci. China: Chem. 2010, 53, 1578-1585. doi:10.1007/s11426-010-4028-6

80. Maddani, M. R.; Prabhu, K. R. J. Org. Chem. 2010, 75, 2327-2332. doi:10.1021/jo1001593

81. Novikov, R. V.; Danilkina, N. A.; Balova, I. A. Chem. Heterocycl. Compd. 2011, 47, 758-766. doi:10.1007/s10593-011-0831-z

82. Mahdavi, M.; Bialam, M.; Saeedi, M.; Jafarpour, F.; Foroumadi, A.; Shafiee, A. Synlett 2015, 26, 173-176. doi:10.1055/s-0034-1379499

83. Easton, N. R.; Cassady, D. R.; Dillard, R. D. J. Org. Chem. 1964, 29, 1851-1855. doi:10.1021/jo01030a044

84. Arya, V.; Grewal, R.; Kaul, C.; David, J.; Honkan, V. Indian J. Chem., Sect. B: Org. Chem. Incl. Med. Chem. 1977, 15, 133-140.

85. Urleb, U.; Neidlein, R.; Kramer, W. Helv. Chim. Acta 1993, 76, 431-440. doi:10.1002/hlca.19930760127

86. Sasmal, P. K.; Chandrasekhar, A.; Sridhar, S.; Iqbal, J. Tetrahedron 2008, 64, 11074-11080. doi:10.1016/j.tet.2008.09.074

87. Scalacci, N.; Pelloja, C.; Radi, M.; Castagnolo, D. Synlett 2016, 27, 1883-1887. doi:10.1055/s-0035-1561985

88. Huang, S.; Shao, Y.; Liu, R.; Zhou, X. Tetrahedron 2015, 71, 4219-4226. doi:10.1016/j.tet.2015.04.080

89. Viart, H. M.-F.; Larsen, T. S.; Tassone, C.; Andresen, T. L.; Clausen, M. H. Chem. Commun. 2014, 50, 7800-7802. doi:10.1039/c4cc00863d

90. Vincent-Rocan, J.-F.; Derasp, J. S.; Beauchemin, A. M. Chem. Commun. 2015, 51, 16405-16408. doi:10.1039/c5cc07212c

91. Short, K. M.; Ziegler, C. B. Tetrahedron Lett. 1993, 34, 71-74. doi:10.1016/S0040-4039(00)60060-6
92. Wipf, P.; Rahman, L. T.; Rector, S. R. J. Org. Chem. 1998, 63, 7132-7133. doi:10.1021/jo981542q

93. Chandrasekharam, M.; Singh, O. M.; Ila, H.; Junjappa, H. Synth. Commun. 1998, 28, 3073-3079. doi:10.1080/00397919808004887

94. Yarovenko, V. N.; Polushina, A. V.; Zavarzin, I. V.; Krayushkin, M. M.; Kotovskaya, S. K.; Charushin, V. N. J. Sulfur Chem. 2009, 30, 327-337. doi:10.1080/17415990902774194

95. Alhalib, A.; Moran, W. J. Org. Biomol. Chem. 2014, 12, 795-800. doi:10.1039/c3ob42030b

96. Sasmal, P. K.; Sridhar, S.; Iqbal, J. Tetrahedron Lett. 2006, 47, 8661-8665. doi:10.1016/j.tetlet.2006.09.157

97. Meng, X.; Kim, S. Org. Biomol. Chem. 2011, 9, 4429-4431. doi:10.1039/c1ob05512g

98. Saeedi, M.; Goli, F.; Mahdavi, M.; Sarihi, P.; Asadipour, A.; Shafiee, A.; Foroumadi, A. J. Chem. Res. 2014, 38, 131-133. doi:10.3184/174751914X13899480812215

99. Urbanaitè, A.; Jonušis, M.; Bukšnaitienè, R.; Balkaitis, S.; Čikotienè, I. Eur. J. Org. Chem. 2015, 7091-7113. doi:10.1002/ejoc.201501063

100. Heugebaert, T. S. A.; Vervaecke, L. P. D.; Stevens, C. V. Org. Biomol. Chem. 2011, 9, 4791-4794. doi:10.1039/c1ob05509g

\section{License and Terms}

This is an Open Access article under the terms of the Creative Commons Attribution License (http://creativecommons.org/licenses/by/4.0), which permits unrestricted use, distribution, and reproduction in any medium, provided the original work is properly cited.

The license is subject to the Beilstein Journal of Organic Chemistry terms and conditions:

(http://www.beilstein-journals.org/bjoc)

The definitive version of this article is the electronic one which can be found at: doi:10.3762/bjoc.13.61 